\title{
THE TEACHING TECHNIQUE OF INDONESIAN IN MADRASAH IBTIDAIYAH: LEARNING FROM MI SURUH 1 PLUS MIFTAHUL ULUM AND MA'ARIF PULUTAN
}

\author{
Nurul Maghfiroh \\ IAIN Salatiga, Salatiga, Indonesia \\ fifiwaluyo@gmail.com \\ Maslikhah \\ IAIN Salatiga, Salatiga, Indonesia \\ maslikhah@iainkudus.ac.id \\ Khusna Widhyahrini \\ IAIN Salatiga, Salatiga, Indonesia \\ khusna@iainsalatiga.ac.id
}

\begin{abstract}
By language skill possessed, students can blow on a variety of knowledge to appreciate literature and to develop themselves sustainably. But there are still many students who do not like Bahasa Indonesia $n$ lessons because of being boring. They were not boring the teacher can use some methods. The Teaching technique was a concrete implementation in the learning process for students. The teachers can change their methods anytime for the same subject. The purpose of this study was to find out various kinds of teaching methods to teach Bahasa Indonesia in the $2^{\text {nd }}$ and $5^{\text {th }}$ Grade in Madrasah Ibtidaiyah (MI) or Primary School level. This research used the qualitative method by interview semi-structured and questionnaire on the theme. The research obtained that MI Suruh 1 Plus used 10 techniques for $2^{\text {nd }}$ Grade and 14 techniques for $5^{\text {th }}$ Grade; MI Miftahul Ulum used 10 techniques for 2nd Grade and 13 techniques for 5th Grade,
\end{abstract}


and MI Maarif Pulutan used 10 techniques for 2nd Grade and 14 techniques for 5th Grade. Variations in techniques used in 3 schools still use almost the same technique, which is different for each school in applying classroom learning techniques according to the material during learning.

Keywords: Teaching Techniques; Indonesian Language; Madrasah Ibtidaiyyah.

\begin{abstract}
Abstrak
Keterampilan berbahasa yang dimiliki siswa mampu menggali berbagai pengetahuan untuk mengapresiasi sastra, dan mengembangkan diri secara berkelanjutan. Tetapi masih banyak siswa yang tidak menyukai pelajaran Bahasa Indonesaia dengan alasan membosankan. Agar tidak bosan guru dapat menggunakan beberapa teknik. Teknik Mengajar adalah implementasi konkrit dalam proses pembelajaran bagi siswa. Para guru dapat mengubah metode mereka untuk mata pelajaran yang sama. Tujuan dari penelitian ini adalah untuk mengetahui berbagai macam teknik pengajaran untuk mengajar Bahasa Indonesia di kelas 2 dan 5 di tingkat Madrasah Ibtidaiyah (MI). Penelitian ini menggunakan metode kualitatif dengan wawancara semi struktur dan angket. Penelitian ini memperoleh bahwa MI Suruh 1 Plus menggunakan 10 teknik untuk kelas 2 dan 14 teknik untuk kelas 5; MI Miftahul Ulum menggunakan 10 teknik untuk Kelas 2 dan 13 teknik untuk Kelas 5; dan MI Maarif Pulutan menggunakan 10 teknik untuk Kelas 2 dan 14 teknik untuk Kelas 5. Variasi teknik yang digunakan di 3 sekolah masih menggunakan teknik yang hampir sama yang membedakan tiap sekolah dalam mengaplikasi teknik pembelajaran dikelas disesuaikan dengan materi saat pembelajaran.
\end{abstract}

Kata Kunci: Teknik mengajar; Bahasa Indonesia; Madrasah Ibtidaiyyah. 


\section{A. Introduction}

Teachers should have a willingness to know more about the basic aims of teaching, such as the goals or targets in teaching and its obligation. Besides the willingness, those teachers are like actors because they are demanded in a unique style to deliver knowledge and are supposed to teach fluently. Meanwhile, another expert supports that teacher is like a planter who plants something and watches the growing process.

Bahasa Indonesia learning is currently still a difficult lesson for students. according to PISA (https://tirto.id/alasan-mengapakualitas-pisa-siswa-indonesia-buruk-enfy) The 2018 survey again placed Indonesian students among the lowest scores on measurements of reading, mathematics, and science. In the literacy category, Indonesia is ranked 6th from the bottom (74) with an average score of 371. Decreased from rank 64 in 2015. This is caused by various things, one of which is how to teach the teacher so that they need to know various techniques to teach Indonesian to students so that it is easier to understand. Bahasa Indonesia is a general subject on some level. Some student thought that was very easy to understand about Bahasa Indonesia, but finally, their ability was done.

Therefore, students' understanding, willingness, and knowledge, in teaching, teachers should use an appropriate method to develop their ability and prestige in Bahasa Indonesia subject. The method consists of planning, selection, and grading the material of language, and technique of teaching methods. However, the methods were not ensured for the effectiveness in the classroom applied. It needs to consider the context of the classroom as well as the level of the students (Munzaki 2016, 11; Trianto 2010, 45)

Bahasa Indonesia's subject for primary school students has a very important role in developing children's language skills. Bahasa Indonesia was the subject that was learned in every 
grade of primary school level as a fundamental subject for the curriculum mechanism. Bahasa Indonesia was learned by step processes to the goal of the Bahasa Indonesia learning. Bahasa Indonesia subject is not mediocre and can be considered quite difficult because each student has a different experience certainly (Lin, Zhang, \& Zheng 2017, 79).

The Bahasa Indonesia subject was carried out from the elementary school (SD) level to the high school (SMA) level. The ability of the student's language not only as a means of communication but also about thinking skills development. Therefore, this text-based learning needs to be immediately understood by observers of Bahasa Indonesia teaching, Bahasa Indonesia teachers, students, and related parties (Kemendikbud, 2013; Sufanti 2013, 39). Bahasa Indonesia is a learning subject based on directed towards the achievement of language skills which includes four aspects, namely listening, speaking, reading, and writing.

There are internal and external factors in Bahasa Indonesia's learning. Internal Factors such as students' satisfaction. Students did not motivate participating in the Bahasa Indonesia learning process and students' interest in learning Indonesian is still lacking. External Factors: the process of implementing Bahasa Indonesia learning conveyed by the teacher is not suitable for students, the teacher rarely uses teaching aids when learning takes place and other factors are the lack of parents' encouragement of their children in learning (Anzar \& Mardhatillah 2017, 54).

For example, the teacher asked the student to write a story about a fun toy. Previously, the child certainly already had provisions for beginning writing lessons in the early grades. Bahasa Indonesia subnect will deliver along with other subjects according to the thematic approach set by the central government. Bearing this in mind, the teacher should arrange learning preparations and teaching Bahasa Indonesia well. The preparation has a problem related to methods and techniques so 
that it must be mastered by the teacher. Teaching and learning were done by various techniques or methods, and approaches that will make it easier for the student to understand what was being learned must always be prioritized by the teacher. The teacher must develop their ability by reading and sharing each other because of the used method in various.

The students can use some variety of knowledge to appreciate literature, and to develop themselves sustainably (Antonio, Soares, \& Parreiras 2018, 4; Budiman 2017, 111). By student's language skills, students can use language as communication tools in socially cultured creatures for the present and the future. Our future is driven by global progress, one of which is very real in the field of technology and information that is increasingly sophisticated with the ability to read, write as we progress, truly so that all progress can be followed properly, correctly, and appropriately (Anatasya et al., 2007) (Faturrohman \& S., 2010).

Bahasa Indonesia learning aims to make students able to have various language skills. The Ministry of National Education explains that learning Indonesian is aimed at making students master the abilities which include: (1) communicating effectively and efficiently following applicable ethics, both verbally and in writing, (2) respecting and proudly using Indonesian as the Language of unity and national language, (3) understanding Bahasa Indonesia subject and use it appropriately and creatively for various purposes, (4) Improving intellectual abilities, emotional, and social maturity, (5) working with literacy works to broaden horizons, refine character and improve knowledge and language skills, (6) respecting and boasting Indonesian literature as a cultural and intellectual treasure of Indonesian people (Siddiq \& Djauhar 2008, 107).

The approach is a way to start something or how to start teaching language. The approach is a theoretical basis for a method. More broadly, the approach is an assumption about 
language, including assumptions that consider language as a habit, some consider language as a communication system that is spoken, and others consider language as a set of rules (Nurhadi $2004,12)$. Approaches can be interpreted as a starting point or our perspective on the learning process. (Prayitno, \& Suciati 2018, 3; Suduc et al., 2015, 8).

Language learning strategies can be described by referring to the intended language skills. Therefore, the following strategies are explained by considering the four language skills of listening, reading, speaking, and writing. Listening skills if you see the needs of today's society, which is experiencing globalization in various aspects of life, language learning must be changed. As has been stated that since 1994, primary and secondary school curricula have been prepared based on competence. Therefore, the language learning curriculum was based on competencies, namely the four language skills such as listening, reading, speaking, and writing, no longer on grammar and linguistics (Laki 2018, 25; Nurhayati $2008,113)$. The four skills are related and the skills can not be separated from listening skills. In the implementation of other skills according to Sugiarti, a teacher who knows various learning techniques language skills and being able to practice them is very helpful in learning Bahasa Indonesia skills (Mirnawati 2017, 94).

Methods are a learning procedure that is focused on achieving goals (Madusari et al., 2009, 2; Sumartini \& Johariyah 2010, 217; Nasution 2017, 10). From the methods, learning techniques are derived applicative. One method can be applied through various learning techniques. Engineering is a concrete method used during the learning process. The teacher can switch techniques even in the same corridor. The technique is a comprehensive design to present regularly the language teaching materials, there are no conflicting parts and all are based on the assumptions of the approach (Parera 1993, 93).

The technique is a trick, strategy, or discovery that was used to complete and perfect and immediate goal (Broto 1980, 
85; Iskandarwassid \& Sunendar 2015, 32). The application of an innovative learning technology needs to be done in learning Indonesian. This needs to be done to maximize the activeness and participation of students in learning (Dibia, Dewantara, \& Widiana 2017, 114).

Following is a general description of language teaching methods and techniques applied, especially the sorting for primary school (Freeman 2000, 178). Meanwhile, according to Saleh Abbas, some techniques for teaching languages in primary schools were shown in Table 1.

Table 1. Techniques for Teaching Languages in Primary School

\begin{tabular}{|c|c|c|c|}
\hline \multirow{2}{*}{ Listening } & \multicolumn{3}{|c|}{ Bahasa Indonesia Teaching Technique } \\
\hline & Speech & Reading & Writing \\
\hline $\begin{array}{l}\text { Listening- } \\
\text { repeating- } \\
\text { speaking }\end{array}$ & $\begin{array}{l}\text { Repeating- } \\
\text { speaking }\end{array}$ & Reading survey & Alphabet writing \\
\hline $\begin{array}{l}\text { Listen-write } \\
\text { (dictation) }\end{array}$ & $\begin{array}{l}\text { Observing- } \\
\text { speaking }\end{array}$ & glance through & $\begin{array}{l}\text { Writing about } \\
\text { activities }\end{array}$ \\
\hline Listening-doing & Describing & Shallow reading & $\begin{array}{c}\text { Writing a } \\
\text { favorite picture }\end{array}$ \\
\hline $\begin{array}{l}\text { Listening- } \\
\text { guessing }\end{array}$ & Answering & Reading out loud & $\begin{array}{c}\text { Writing-drawing } \\
\text { a shapes }\end{array}$ \\
\hline $\begin{array}{c}\text { Extending the } \\
\text { sentence }\end{array}$ & Asking & Silent reading & $\begin{array}{c}\text { writing stories of } \\
\text { archival form }\end{array}$ \\
\hline $\begin{array}{c}\text { Completing the } \\
\text { story }\end{array}$ & Question digging & Critical reading & $\begin{array}{l}\text { Write how-to- } \\
\text { play something }\end{array}$ \\
\hline $\begin{array}{l}\text { Making a } \\
\text { summary }\end{array}$ & $\begin{array}{l}\text { Continuing the } \\
\text { story }\end{array}$ & Peruse & $\begin{array}{c}\text { Writing posters } \\
\text { or billboards }\end{array}$ \\
\hline $\begin{array}{c}\text { Finding an } \\
\text { object }\end{array}$ & Recounting & $\begin{array}{c}\text { Reading } \\
\text { comprehension }\end{array}$ & $\begin{array}{c}\text { Writing postal } \\
\text { objects }\end{array}$ \\
\hline Chain whisper & Paraphrasing & & Writing daily life \\
\hline $\begin{array}{c}\text { Continue the } \\
\text { story }\end{array}$ & $\begin{array}{l}\text { Fabrication of } \\
\text { picture stories }\end{array}$ & - & $\begin{array}{l}\text { Writing favorite } \\
\text { toys }\end{array}$ \\
\hline Paraphrasing & Roleplaying & - & - \\
\hline Keywords & Interviewing & - & - \\
\hline
\end{tabular}

Source: (Abbas, 2006) 
There are two grades in primary school level, such as low class (1st grade, 2nd grade, and three grade) and high-class 4th grade, 5 th grade, and 6th grade (Anitah 2008, 84). The range of age in primary school, which is between 6 th or 7 th to 12 th years. The age of students in the low-class group, which is 6th or 7th to 8th or 9th years. Students in this group are included in the range of early childhood. This early age is a short period but is very important for one's life. Therefore, all the potential possessed by children needs to be encouraged so that it will develop optimally. The purpose of this study was to determine the techniques used by teachers in learning Bahasa Indonesia for low and high classes. The researcher chose class 2 to represent the low class where students in grade 2 were able to follow teacher learning with more concentration while the selection of grade 5 to represent the high class between grades 4 and 6 is because grade 5 students are more ready to study seriously than grade 4 , and grade 5 learning has not focused on national exams like grade 6 so that teachers can use a variety of techniques.

\section{B. Discussion}

\section{Methods}

This research used qualitative research methods, where the teacher was the subject research. The qualitative method was used to find out various methods to teach Bahasa Indonesia subject for 2nd and 5th grade of primary school level and to understand the effect of changing methods. The activities in this research were: conducting conceptual-theoretical studies on various Indonesian teaching techniques in the low and high-class classes, and looking for articles from relevant previous research. Conducting in-depth field research on teaching techniques for teachers in 2nd and 5th grades with the same theme.

In this study, data were obtained from MI Suruh 1 Plus, MI Miftahul Ulum Jipo Kepohbaru, and MI Ma'arif Pulutan. Data were 
obtained by using the semi-structured of oral interview method and questionnaire on 1st theme with the class teacher. This research had focused 2 nd as below and 5th grade as upper class in Bahasa Indonesia subject in teaching. Data analysis using the Analysis model Interactive by Miles and Huberman which divides the analysis activities into several sections, namely: data collection, data reduction, presentation of data, and conclusions (Ilyas 2016, 94). First, make a list of questions to interview the class teacher; Second, make a questionnaire containing what techniques the teacher uses in Bahasa Indonesia lessons theme; Third, collect data; Fourth, analyze the data; Fifth, make conclusions.

\section{Bahasa Indonesia Teaching Technique}

The condition of Bahasa Indonesia learning at MI Suruh 1 Plus there are still many students who do not dare to be asked by the teacher to read, so learning is a little hampered because some of the time runs out waiting for students who dare to read. At MI Ma'arif Pulutan at that time was a little less conducive, some children still prefer to chat with their classmates instead of paying attention to teachers or friends who are reading. Meanwhile, at MI Miftahul Ulum some students still spell writing when asked to read by the teacher.

It was found that there were 11 learning techniques applied to Bahasa Indonesia in the three schools, as explained by Sastromiharjo Mix methods and techniques that can foster student interest in learning and interested in Bahasa learning. The teacher brought the techniques in Bahasa Indonesia teaching in 2nd grade in three different schools grouped into four Bahasa Indonesia competencies that showed in Table 2. 
Table 2. Various Technique of Bahasa Indonesia Teaching in 2nd grade of MI level

\begin{tabular}{|c|c|c|c|}
\hline \multirow{2}{*}{ Competency } & \multicolumn{3}{|c|}{ Madrasah Ibtidaiyah (MI) } \\
\hline & Suruh 1 Plus & Miftahul Ulum & Ma'arif Pulutan \\
\hline \multirow{3}{*}{ K1: Listening } & $\begin{array}{l}\text { Observing- } \\
\text { Listening and } \\
\text { repeating }\end{array}$ & $\begin{array}{l}\text { Observing-Listening } \\
\text { and repeating }\end{array}$ & $\begin{array}{l}\text { Observing- } \\
\text { Listening and } \\
\text { repeating }\end{array}$ \\
\hline & Finding object & Finding object & Finding object \\
\hline & & Observing-doing & \\
\hline \multirow{4}{*}{ K2: Speaking } & $\begin{array}{l}\text { Observing- } \\
\text { speaking }\end{array}$ & Observing-speaking & $\begin{array}{l}\text { Observing- } \\
\text { speaking }\end{array}$ \\
\hline & $\begin{array}{l}\text { Repeating- } \\
\text { speaking }\end{array}$ & Repeating-speaking & $\begin{array}{l}\text { Repeating- } \\
\text { speaking }\end{array}$ \\
\hline & Answering & Asking & Asking \\
\hline & Describing & - & Answering \\
\hline K3: Reading & $\begin{array}{l}\text { out loud } \\
\text { reading }\end{array}$ & out loud reading & out loud reading \\
\hline \multirow{3}{*}{ K4: Writing } & $\begin{array}{l}\text { Alphabet } \\
\text { writing }\end{array}$ & Alphabet writing & $\begin{array}{l}\text { Alphabet } \\
\text { writing }\end{array}$ \\
\hline & $\begin{array}{l}\text { Write drawing } \\
\text { shapes }\end{array}$ & $\begin{array}{l}\text { Write drawing } \\
\text { shapes }\end{array}$ & $\begin{array}{l}\text { Write drawing } \\
\text { shapes }\end{array}$ \\
\hline & Describing & Describing & Describing \\
\hline
\end{tabular}

In the low class, the techniques used in K1 (1st competency), the three teachers use repeated speech and find objects according to the teacher, this technique is a sure thing because for low classes the easiest way to make children pay attention to the teacher is to run this method by Ratnasari. practiced in the low class and the high class by adjusting the material to the abilities of the students. The use of repetitive listening methods in learning that can encourage the growth of student pleasure in lessons, facilitate students in learning, grow and increase motivation in assignments, it provides benefits for students to understand the lesson so that it supports students in achieving good and correct speaking skills but at MI Miftahul Ulum added the watch to do 
technique because according to the teacher the addition of this technique can make students more active (Ratnasari, Arini, \& Murda 2016, 10). The see-do method is not only useful in learning Indonesian, but also useful for developing students' knowledge widely (Harini, Kristiantari, \& Manuaba 2014, 4).

For K2, the Realization of the KD Technique among elementary school students with Javanese cultural background tends to be expressed in indirect and nonliteral modes rather than indirect or literal modes. This realization illustrates that elementary school students are still in a period of mental lingual development so that they still need guidance that is positive, polite, and characterized by their parents, teachers, and community in terms of language and acting (Prayitno 2011, 205). The three schools use the see-speak and rephrase technique, the reason the teacher uses this is because in speaking competence this technique can make it easier for the teacher to invite students to practice speaking. The method of seeing words to improve speaking skills in students (Nurhasanah 2018, 335) and several other techniques in each school, MI Suruh 1 Plus adds techniques to answer questions and describe describing means explaining, explaining, describing, or describing something (Abbas 2006, 81), where according to the MI Suruh 1 teacher this technique was able to help students speak correctly through students' stories. MI Miftahul Ulum added the questioning technique while MI Ma'arif Pulutan added the technique of asking and answering questions using effective and efficient question techniques to cause changes in behavior and student responses to the topics discussed, so that the teaching and learning process would be as expected (Lazuardi 2017, 92).

In K3, the three teachers from each school used the same technique, namely reading aloud, an effort to improve reading skills for students are very necessary. Reading skills are a must mastered from an early age, since they were in elementary school, especially in the classes the beginning, namely class 1 and class 2 (Jamila 2014, 146). 
And K4, Writing is a representation of part of the unity of language expression. Writing is very important for education because it makes it easy for students to think. The three teachers use the same technique as well as writing the alphabet, writing pictures, and describing because according to the three teachers, writing the alphabet is a basic skill that must work for students starting from low grade(Kustiyah 2014, 197).

The teacher's techniques in teaching Indonesian in high class (class V) in three different schools grouped into four Bahasa Indonesia competencies that showed in Table 3.

Table 3. The Various Technique in 5th grade (high class)

\begin{tabular}{|c|c|c|c|}
\hline Competency & MI Suruh 1 Plus & MI Miftahul Ulum & $\begin{array}{l}\text { MI Ma'arif } \\
\text { Pulutan }\end{array}$ \\
\hline \multirow{5}{*}{ K1: Listening } & $\begin{array}{l}\text { Listen-write } \\
\text { (dictation) }\end{array}$ & $\begin{array}{l}\text { Listen-write } \\
\text { (dictation) }\end{array}$ & $\begin{array}{l}\text { Listen-write } \\
\text { (dictation) }\end{array}$ \\
\hline & Listen-do it & Listen-do it & Listen-do it \\
\hline & Make a summary & Make a summary & Make a summary \\
\hline & $\begin{array}{l}\text { Continue the } \\
\text { story and } \\
\text { Complete the } \\
\text { story }\end{array}$ & $\begin{array}{l}\text { Continue the story } \\
\text { and Complete the } \\
\text { story }\end{array}$ & $\begin{array}{l}\text { Continue the } \\
\text { story and } \\
\text { Complete the } \\
\text { story }\end{array}$ \\
\hline & Paraphrasing & Paraphrasing & Paraphrasing \\
\hline \multirow{4}{*}{ K2: Speaking } & Asking & Asking & Asking \\
\hline & See-said & See-said & See-said \\
\hline & Roleplaying & Roleplaying & Roleplaying \\
\hline & Interview & - & - \\
\hline \multirow{2}{*}{ K3: Reading } & Reading silently & Reading silently & Reading silently \\
\hline & Peruse & Peruse & Peruse \\
\hline \multirow{4}{*}{ K4: Writing } & Writing activities & Writing activities & Writing activities \\
\hline & $\begin{array}{l}\text { Writing posters } \\
\text { or billboards }\end{array}$ & $\begin{array}{l}\text { Writing posters or } \\
\text { billboards }\end{array}$ & $\begin{array}{l}\text { Writing posters } \\
\text { or billboards }\end{array}$ \\
\hline & $\begin{array}{l}\text { Fill in the } \\
\text { sentence }\end{array}$ & Fill in the sentence & $\begin{array}{l}\text { Fill in the } \\
\text { sentence }\end{array}$ \\
\hline & - & - & Write a diary \\
\hline
\end{tabular}


In the high class for $\mathrm{K} 1$, the three teachers used the same technique, namely listen-write, watch-do in teaching and learning activities using the watch-do method, students are activated both mentally and physically in mastering the subject matter, making a summary, finish and continue the story and paraphrase (Harini et al., 2014, 2). Based on the results of the study, Bahasa Indonesia and Literature teachers who teach at Mutiara Singaraja Elementary School are advised to use storytelling techniques based on Balinese culture in writing learning so that learning is more effective and can achieve learning goals (Dibia et al., 2017, 115).

For K2, MI Suruh 1 Plus teachers use the technique of asking, talking, role-playing, and interviewing then teachers at MI Miftahul Ulum and MI Ma'arif Pulutan also use the same technique, only they do not use interview techniques, because according to the MI teacher Ma'arif Pulutan and MI Miftahul Ulum, student interview techniques are less interested and do not focus on learning, this is following the theory which argues that there is also the fact that students are less motivated to learn to interview because students feel that interview learning is less useful about their daily life and with student life at times.

The reading competence of the three teachers uses the same technique for high-grade students reading silently and perusing according to the teachers who read carefully can improve student concentration in line with Kasarudin's research that the active learning strategy of reading guides can be relied upon as a good strategy to improve Indonesian learning outcomes (Kasarudin 2017, 10).

And K4, the three teachers are still the same in using techniques, namely writing activities, writing posters, and filling in blank sentences but the MI Ma'arif Pulutan teacher adds 1 technique, namely writing a diary. The diary book is a medium that students can use to write stories or events that they think urgent. This can be a way to familiarize students with writing as well as to overcome their difficulties when they want to write something more structured 
(Sugiastuti, Tudana, \& Agung 2015, 3). the MI Ma'arif teacher chose this technique because according to him, by writing a diary students could reveal anything. what students feel and think, making it easier for teachers to understand students' understanding.

\section{Innovative Bahasa Indonesia Learning Techniques}

Teachers often use a learning approach that is still monotonous. Apart from approaches and strategies, Indonesian language learning can be done by various techniques or strategies. Usage is various innovative techniques and methods certainly can creating a learning situation conducive (Rosmawati 2020, 869). Learners in this connection participate directly involved in absorbing information and restate the results records of information obtained accordingly with the individual abilities of students. Through a dynamic learning process, it is hoped that a form will be created oral communication between students and other learners are patterned through listening, speaking, reading, and writing, so that the atmosphere of learning not boring.

Listening skills are receptive language skills (Mansyur 2016, 160). Listening learning can be done alone or integrated with learning to speak or read. The important thing that needs to be done is the need to pay attention to the listening process itself. In learning to listen, the teacher can teach students a variety of skills, such as listening quickly and listening comprehension. Teachers can also teach listening based on their content such as science or technology, media can also be used such as LCDs, and other types of listening materials such as popular, poetry, and drama. Also, teachers can develop students' listening skills through questions, grouping, and mapping, reading aloud, telling stories, and interviews (Salsabilla \& Zafi, 2020, 36).

One of the innovations in learning to speak is drama activity. Drama can be done through a learning model with role-playing methods, favorite objects, and drama performances (Mansyur 2016, 159; Masruroh 2016, 30). Role-playing can be done either 
with the script that is already available. Meanwhile, drama performances can be performed by students in the classroom with all simplicity according to the learning situation in the classroom.

The application of the scrambling method can improve the reading comprehension ability of students in the Indonesian language subject (Dianuraini 2010, 117; Hendrawan 2010, 38; Masruroh 2016, 79; Suratno 2014, 39). Grade VA Nurul Islam Purwoyoso Elementary School Semarang Academic Year $2015 / 2016$. This is indicated by the increase in the average value of the evaluation test results in cycle I by 74.5 , while the evaluation test in cycle II reached an average value of 86.25 which has exceeded the achievement indicator, namely the learning outcomes of students $\geq 70$ (Masruroh 2016, 79). an example of innovation in learning to read. Tell me what you see technique is a teaching technique that can foster students' ability to speak. Increased speaking skills occur after the teacher and researcher make some efforts to improve abilities speak in Indonesian on the material using the telephone tell me what you see technique (Daryanti $2013,6)$. Besides the scramble technique, there are also skimming techniques. Skimming is to read quickly to find out the contents of a discourse assisted by lines of words. Skimming is used to get the main idea from a discourse. So you know the picture of the contents of the discourse. Skimming to get the main idea from a discourse so that it can answer questions correctly (Rahim 2005, 61). Skimming techniques can improve the reading comprehension skills of Deaf students by using Skimming Techniques at SMK N 4 Padang (Amna, Azwandi, \& Yunus 2013, 861).

Brainwriting is a learning technique that is delivered through written or written form. Based on the results of the implementation of student learning, writing techniques it can be concluded that the brainwriting technique is thought to improve the ability of students in writing poetry. Brainwriting techniques increase students' motivation in learning to write poetry. Brainwriting techniques can make it easier for students 
to express ideas, ideas so that students can achieve the expected results (Azizah 2015, 138).

\section{Conclusions}

The several of teaching techniques had been used in Madrasah Ibtidaiyah (MI) level by same technique for each class, in MI Suruh 1 Plus for 2nd grade used by repeating-speaking, finding objects, observing-speaking, repeating-speaking, answering questions, describing/description, reading aloud, writing the alphabet, writing the shape of the picture, and describing. The 5th grade of MI Suruh 1 Plus used writing, reading, summarizing, completing and continuing stories, paraphrasing, asking, lookingsaying, playing roles, interviewing, reading silently, reading carefully, writing activities, writing posters, and fill in sentences technique. The 2 nd grade of MI Miftahul Ulum got more and more of the work only. And, MI Ma'arif Pulutan had additional high-class writing the daily life. Variations in techniques used in 3 schools still use almost the same technique, which is different for each school in applying classroom learning techniques according to the material during learning. The various methods gave contribute to the Bahasa Indonesia learning process, so the teacher may apply the methods in various situations also. In this case, apart from teachers, the role of schools is very important in advancing teacher quality. Schools can provide provision for training or seminars for teachers so that they have additional knowledge in carrying out the learning process so that they can develop teacher abilities. 


\section{REFERENCES}

Abbas, S. (2006). Pembelajaran Bahasa Indonesia Yang Efektif di Sekolah Dasar. Departemen Pendidikan Nasional.

Amna, P., Azwandi, Y., \& Yunus, M. (2013). Meningkatkan Kemampuan Membaca Pemahaman pada Siswa Tunarungu dengan Menggunakan Teknik Skimming. Jurnal Ilmiah Pendidikan Khusus, 2(3), 854-862.

Anatasya, D., Yanti, F. W., Mellenia, R., Angreska, R., Putr, S., Kuntarto, E., \& Noviyanti, S. (2007). Pembelajaran Bahasa Indonesia di Sekolah Dasar. Jurnal Kajian Kebahasaan, 1-9.

Antonio, M., Soares, C., \& Parreiras, F. S. (2018). A literature review on question answering techniques, paradigms and systems. Journal of King Saud University - Computer and Information Sciences, 8(5), 1-12.

Anzar, S. F., \& Mardhatillah. (2017). Analisis Kesulitan Belajar Siswa pada Pembelajaran Bahasa Indonesia di Kelas V SD Negeri 20 Meulaboh Kabupaten Aceh Barat Tahun Ajaran 2015/2016. Bina Gogik, 4(1), 53-64.

Azizah, A. (2015). Pembelajaran Menulis Puisi dengan Memanfaatkan Teknik Brain Writing Pada Peserta Didik SD/MI Kelas V. Jurnal Ilmiah "PENDIDIKAN DASAR," 2(2), 136-140.

Baskoro Adi Prayitno, Suciati, E. T. (2018). Enhancing Students' Higher Order Thinking Skills in Science Throuh. Journal Od Baltic Science Education, 17(6), 1046-1055.

Broto, A. S. (1980). Pengajaran Bahasa Indonesia. Bulan Bintang.

Budiman, A. (2017). Behaviorism in Foreign Language Teaching Methodology. English Franca, 1(02), 101-114.

Daryanti, E. (2013). Peningkatan Kemampuan Berbicara Siswa dengan Menggunakan Teknik Tell Me What You See pada Mata Pelajaran Bahasa Indonesia pada Siswa Kelas IV SD Negeri Temboro IV Karangtengah Wonogiri Tahun Pelajaran 2012/2013. Universitas Muhammadiyah Surakarta. 
Dianuraini, D. (2010). Penggunaan Teknik Scramble Melalui Media Gambar Untuk Meningkatkan Kemampuan Membaca Permulaan Kalimat Sederhana Siswa Kelas I SD Negeri 3 Grogol Kecamatan Gunungjati Kabupaten Cirebon, Semarang. Universitas Negeri Semarang.

Dibia, I. K., Dewantara, I. P. M., \& Widiana, W. (2017). Pemberdayaan Teknik Bercerita Berbasis Budaya Bali Dalam Pembelajaran Keterampilan Menulis Karangan Pribadi Siswa Kelas V SD Mutiara Singaraja. Journal of Education Research and Evaluation, 1(2), 113-119.

Faturrohman, P., \& S., S. M. (2010). Strategi Belajar Mengajar Melalui Penanaman Konsep Umum \& Konsep Islami. Refika Cipta.

Freeman, D. L. (2000). Techniques and Principles in Language Teaching. Oxford University Press.

Harini, N. K. J. S., Kristiantari, M. . R., \& Manuaba, I. . S. (2014). Pengaruh Metode Simak-Kerjakan Terhadap Hasil Belajar Menyimak Cerpen Siswa Kelas V SD Negeri 17 Dauh Puri. Jurnal Mimbar PGSD Universitas Pendidikan Ganesha, 2(1), 1-11.

Hendrawan, H. N. (2010). Peningkatan Kemampuan Membaca Pemahaman Melalui Teknik Scramble Pada Siswa Kelas IV Sekolah Dasar Negeri Plumbon Kecamatan Temon Kabupaten Kulon Progo, Yogyakarta. Universitas Negeri Yogyakarta.

Ilyas. (2016). Pendidikan Karakter Melalui Homeschooling. Journal of Nonformal Education, 2(1), 91-98.

Iskandarwassid, \& Sunendar. (2015). Strategi Pembelajaran Bahasa. Remaja Rosdakarya.

Jamila. (2014). Meningkatkan Kemampuan Membaca Nyaring dengan Lafal dan Intonasi yang Benar dalam Pembelajaran Bahasa Indonesia Menggunakan Metode Drill pada Siswa Kelas 1B SDN Tanggul Wetan 02 Jember. Pancaran, 3(2), 145-156. 
Kasarudin, R. (2017). Keterampilan Membaca Teliti dengan Strategi Pembelajaran Aktif Reading Guide Siswa Kelas $X$ SMK Bintan Insani Tanjung Pinang.

Kemendikbud. (2013). Standar Kompetensi Dasar Sekolah Dasar (SD)/Madrasah Ibtidaiyah (MI). Kementrian Pendidikan dan Kebudayaan.

Kustiyah. (2014). Meningkatkan Kemampuan Menulis Huruf Abjad Melalui Teknik Menulis di Udara pada Siswa Kelas 1B SDN Klatan 02 Jember. Pancaran, 3(2), 195-204.

Laki, R. (2018). Strategi Pembelajaran Bahasa Indonesia di Era Kurikulum Tingkat Satuan Pendidikan (KTSP). Jurnal Pendidikan Dan Pembelajaran, 1(1), 23-29.

Lazuardi, D. R. (2017). Teknik Guru Bertanya pada Pembelajaran Bahasa Indonesia Siswa Kelas XI RPL 3 SMK Tugumulyo. Jurnal KAjian Bahasa, Sastra Dan Pengajaran, 1(1), 90-98.

Lin, C., Zhang, Y., \&Zheng, B. (2017). The Roles of Learning Strategies and Motivation in Online Language Learning: A Structural Equation Modeling Analysis. Computers \& Education, 113, 75-85. https://doi.org/10.1016/j.compedu.2017.05.014

Madusari, E. A., Alamsyah, T., \& Dihanti, E. (2009). Metodologi Pembelajaran. Depdiknas.

Mansyur, U. (2016). Inovasi Pembelajaran Bahasa Indonesia Melalui Pendekatan Proses. Jurnal Retorika, 9(2), 90-163.

Masruroh, A. (2016). Upaya Meningkatkan Kemampuan Membaca Pemahaman Siswa dengan Menggunakan Teknik Scramble Mata Pelajaran Bahasa Indonesia pada Kelas VA SD Nurul Islam Purwoyoso Semarang Tahun Pelajaran 2015/2016.

Mirnawati. (2017). Peningkatan Keterampilan Berbicara Siswa Kelas I SD melalui Media Gambar Seri Di SDN 06 Lubuk Alung Kabupaten Padang Pariaman. JPPI (Jurnal Penelitian Pendidikan Indonesia), 3(2), 94-109.

Munzaki, D. F., Suadah, L., \& Risdaneva. (2016). Teaching Methods Used by Students of Department of English Language 
Education of UIN Ar-Raniry in Teaching English at English Course. Englisia Journal, 4(1), 10-26.

Nurhadi. (2004). Pembelajaran Konstekstual dan Penerapannya dalam KBK. UM Press.

Nurhasanah. (2018). Upaya Meningkatkan Keterampilan Berbicara Melalui Metode Pembelajaran Lihat Ucap di Kelas 1 SDN 005 Koto Sentajo Kecamatan Sentajo Raya. Jurnal PAJAR, 2(3), 351-355.

Parera, J. D. (1993). Leksikon. Gramedia Pustaka Utama.

Prayitno, H. J. (2011). Teknik dan Strategi Tindak Kesatuan Direktif di Kalangan ANDIK SD Berlatar Belakang Budaya Jawa. Kajian Linguistik Dan Sastra, 23(2), 204-218.

Rahim, F. (2005). Pengajaran Membaca Di Sekolah Dasar. Bumi Aksara.

Ratnasari, N. K. W., Arini, N. W., \& Murda, I. N. (2016). Penerapan Metode Simak Ulang-Ucap Berbantuan Media Audio Untuk Meningkatkan Keterampilan Berbicara pada Mata Pelajaran Bahasa Indonesia Kelas II. E-Journal PGSD Universitas Pendidikan Ganesha, 4(1), 1-12.

Rosmawati, E. (2020). Iovasi Pembelajaran Bahasa Indonesia Melalui Pendekatan Proses. Prosiding Seminar Nasional Pendidikan Program Pascasarjana Universitas PGRI Palembang, 869.

Salsabilla, S., \& Zafi, A. A. (2020). Kecerdasan Interpersonal Peserta Didik Sekolah Dasar. Jurnal Pendidikan Dan Pembelajaran Dasar, 7(1), 35-42. http://ejournal.radenintan.ac.id/index. php/terampil/index

Siddiq, M., \& Djauhar. (2008). Pengembangan Bahan Pembelajaran $S D$. Depdiknas.

Sri Anitah. (2008). Strategi Pembelajaran di SD. UT Press.

Suduc, A., Bizoi, M., \& Gorghiu, G. (2015). Inquiry Based Science Learning in Primary Education. Procedia - Social and Behavioral Sciences, 205(May), 474-479. https://doi. org/10.1016/j.sbspro.2015.09.044 
Sufanti, M. (2013). Pembelajaran Bahasa Indonesia Berbasis TEKS: Belajar dari Ohio Amerika Serikat. Universitas Muhammadiyah Surakarta.

Sugiastuti, N. P. M., Tudana, M., \& Agung, A. A. G. (2015). Pengaruh Penggunaan Diary Book Terhadap Kemampuan Menulis Bahasa Inggris Ditinjau dari Motivasi Belajar Siswa Kelas X SMK Restumning Perean. E-Jurnal Program Pascasarjana Universitas Ganesha, 6(1), 1-12.

Suratno, A. (2014). Peningkatan Kemampuan Membaca Pemahaman Menggunakan Teknik Scramble Wacana Siswa Kelas IVA SD N Tukangan Yogyakarta. Universitas Negeri Yogyakarta.

Trianto. (2010). Mendesain Model Pembelajaran Inovatif-Progresif. Kencana Prenada Media Group. 
246 | Nurul Maghfiroh, Maslikhah, and Khusna Widhyahrini

Elementary Vol. 8 No. 2 Juli - Desember 2020 